\title{
Too dependent to participate: ward committees and local democratisation in South Africa
}

\section{Laurence Piper* \& Roger Deacon**}

${ }^{*}$ Department of Political Studies, University of the Western Cape, Bellville, South Africa, ${ }^{* *}$ School of Education, University of KwaZulu-Natal, Durban, South Africa

\begin{abstract}
Will participatory local government structures help deepen democracy in South Africa? That is the proclaimed purpose of the ward committee system, the centrepiece of post-apartheid local government reform, intended to facilitate deliberative democratic decision making. Drawing on a case study of the Msunduzi municipality, it is argued here that ward committees, as yet barely functional seven years since first being established, have from the outset been caught up in relations of dependency with ward councillors, political parties and the municipality itself, and that these relations threaten to undermine the democratic dividends that the committees are expected to yield.
\end{abstract}

Keywords: Democratisation, participatory local governance, invited spaces, policy implementation

\section{Introduction}

Post-apartheid South Africa is barely ten years old, yet the core institutions of the new democracy are well known, all except for those of local government. While all 284 municipal councils in South Africa are now democratically elected, in the last few years the national government has supplemented this by building a public participation component into municipal decision making. Described in the relevant legislation as 'participatory governance', public participation is now a requirement of many statutory municipal processes, including the annual budget, development planning and service-delivery agreements. In accordance with this, the institution of the ward committee was introduced as the primary participatory government structure for local communities.

The reasons for the innovation of 'participatory governance' are many and include redressing the remoteness of national and provincial governments, improving the responsiveness of local government, especially as regards service delivery and local economic development, as well as an expressed ideological commitment to deepening democracy. The key issue, however, is will these 'invited spaces' actually work? More specifically, will ward committees work? Will they help make local government better informed about, and more responsive to, local communities? Will they enable local communities to impact meaningfully on council decision- making processes? In short, will they help deepen local democracy in South Africa? 
We think that this is unlikely. Our research into the operation of ward committees in the Msunduzi municipality of KwaZulu-Natal, which includes the city of Pietermaritzburg, found that the ward committee system was feeble and poorly developed and incapable of having any impact upon council processes. More specifically, we found that the functioning of ward committees is overly dependent on (1) the performance of ward councillors, (2) the political will of the local party and (3) the support of the municipality.

On one level, this is to do no more than to suggest that ward committees can deepen the democracy of municipal decision making when the councillors are capable, the local party supports the local community on key issues, and the municipality is well run. However, should any of these elements not be in place, as is currently the case in South Africa, then there is reason to assume that ward committees will make little or no difference. In sum, the ward committee system is too dependent on certain key individuals, political parties and the municipality for it to underwrite public participation in local governance.

In making this argument we begin by situating ward committees in the context of post-apartheid local government reform and, more especially, the attempt to build a public participation component into decision making at local government level. We then examine the practice of ward committees in the Msunduzi municipality, outline our findings and explore their implications for the operation of the ward committee system more broadly.

\section{Ward Committees and Democratic Local Government Reform}

With the advent of democracy in South Africa, political institutions were overhauled and democratised in national, provincial and, more recently, local government spheres. The local government sphere was the last to be reformed, not least as it was seen as less important than the others. As former President Thabo Mbeki (in Vanderhaegen, 2005) admitted in the Local Government Bargaining Council Sector Summit, 'the primary focus has been on national government as "absolutely important", provincial government as "important" and local government as "well, it exists"'.

Nevertheless, when attention was finally given to local government, it was undivided and has profoundly transformed the landscape. The number of municipalities was rationalised but, at the same time, their powers and duties were expanded, including a right to tax, a service delivery responsibility and a built-in development requirement. More pertinently, municipalities are expected to operate in a more democratic, accountable and participatory manner, and to complement their formal structures of representative government with a system of 'participatory governance' involving all residents.

\section{Participatory Governance}

Notably, 'participatory governance' is not representative democracy, understood as the regular election of councillors, but refers to the manner in which municipalities govern between elections. Also termed 'community participation' or 'public participation', it emphasizes 'the relation between government and those who are governed' and is intended to take the 'views and interests of those affected by government more seriously than in the past' (DPLG, 2004a: 5). There are three substantive aspects to the innovation of 'participatory governance': the redefinition of the municipality, requirements for public participation, and ward committees. 
Since 1998, when the Municipal Structures Act (Act no. 117) provided for the establishment of ward committees, the local community was included alongside councillors and administrators in the legal definition of a municipality. This innovation is claimed to be unique in the world, but above the symbolic affirmation of residents as also constituting the municipality and, therefore, in some fundamental sense also 'owning' local government, there seem to be no immediate practical implications in respect of public participation.

The second innovation is a set of requirements for public involvement in various decision-making processes. Thus, Chapter 4 of the Municipal Systems Act (2000) details the procedures municipalities must adopt to promote community participation. These include the receipt, processing and consideration of petitions and complaints lodged by members of the local community; notification and public comment procedures; public meetings and hearings; consultative sessions with locally recognised community organisations and (where relevant) traditional authorities; and reporting back to the local community. Especially important here are the imperatives to public consultation around the annual budget, the Integrated Development Planning (IDP) review process, the Performance Management System (PMS), service delivery contracting and all by-laws, amongst others.

While clearly important, these requirements for public participation in local government processes are arguably outdone by the one structural element of 'participatory governance': ward committees.

\section{Ward Committees}

Ward committees are first mentioned in the 1998 White Paper on Local Government, but it is the Municipal Structures Act that outlines them in some detail. This Act provides for ward committees to be established in each ward of cities and towns, if the municipality so chooses, though, of late, government has suggested that the ward committee system be made compulsory for all municipalities, including rural areas and villages (Msengana-Ndlela, 2006).

Chaired by the ward councillor, ward committees are intended to consist of up to ten people representing 'a diversity of interests' in the ward, with women 'equitably represented'. In respect of their role, Section 74(a) of the Municipal Structures Act states that ward committees 'may make recommendations on any matter affecting its ward (i) to the ward councillor; or (ii) through the ward councillor, to the metro or local council, the executive committee, the executive mayor or the relevant metropolitan subcouncil'. Section 74(b) adds that a ward committee 'has such duties and powers as the metro or local council may delegate to it in terms of section 32'. Notably, the 'Guidelines for the Establishment and Operation of Municipal Ward Committees' (Notice 965 of 2005) stipulates that the 'duties and powers' delegated to ward committees may not include executive powers (Section 5(3)(d)), but instead emphasises their role in communication and mobilisation.

This statutory 'disempowerment' of ward committees raises the question of whether ward committees are even designed to deepen local democracy. As Bryan (2004: 294) noted, real democracy requires that governments 'trust their citizens enough to make mistakes on 
matters of importance'. Yet, while ward committees are only advisory bodies, it is also beyond doubt that deliberation is a key element in the decision-making process and ward committees are empowered to do just this. This seems consistent with the observation of Yunus Carrim (2003), an MP from the ruling African National congress (ANC), former chairperson of the Local Government Portfolio Committee, and architect of much local government legislation: 'Essentially, the system overall seeks to provide a balance between giving residents the fullest space to participate in municipal affairs and ensuring the right of councillors to ultimately govern'.

The 2005 Notice is significant in three more respects. First, it encourages ward committees to engender constructive relations between state and society. Ward committees are exhorted in Section 5(1)(3)(b)(v) to 'ensure constructive and harmonious interaction between the municipality and community through the use and co-ordination of ward residents meetings and other community development forums'. Secondly, ward committees have a near-exclusive claim to legitimacy reflected in Section 5(3)(a) which declares them to be 'an official specialised participatory structure in the municipality'. Thirdly, the Notice places much emphasis on the non-partisan role of ward committees, with Section 2 defining the status of a ward committee as 'an advisory body' which 'is independent' and 'must be impartial and perform its functions without fear, favour or prejudice'.

\section{Why Ward Committees?}

That government is keen on ward committees is beyond doubt. By late 2004 the national Department for Provincial and Local Government (DPLG, 2004a: 17) was reporting that, with the exclusion of the Western Cape where the 'process was in progress', no less than 86.8 per cent of all possible ward committees had been established in the rest of the country. In KwaZulu- Natal some 302 or 83.43 per cent of ward committees had been formed, with just 60 outstanding. But why this emphasis on ward committees and, for that matter, why the drive towards public participation in local governance? While this paper does not definitively answer this question, it does identify three major contributing factors: ideology, international best practice and local government responsiveness.

A survey of speeches, articles and documents by key government and ANC officials confirms the significance of ideology. As a national liberation movement opposed to apartheid oppression, the ANC has long affirmed democratic governance and, indeed, at times the movement and its allies have affirmed 'participatory democracy' or 'people's power' as the preferred version of democratisation (see ANC, 1986). In more recent, post-apartheid times, government documents have affirmed public participation as 'deepening democracy' in a way consistent with the ideological heritage of the ANC, more specifically the 'national democratic revolution' (Carrim, 2003). It is said that public participation gives expression to the slogan, 'the people shall govern', which is the primary tenet of the ANC's most important ideological document, the Freedom Charter of 1955 (see DPLG, 2005: 1).

The second reason why government is enthusiastic about public participation is its currency in governance around the globe, especially in those countries that form part of the 'progressive governance' network to which South Africa also belongs. This factor should not be ignored, as the practice of governance in South Africa relies quite heavily on consultants, 
many of whom advocate 'best practices' developed elsewhere in the world. Hence, a DPLG document (2004a: 5) notes:

Throughout the world, municipalities have come to appreciate that the relation between government and those who are governed is as important as government itself. This is what is meant when people speak of the shift from government to governance. Governance is a way of governing. It takes views and interests of those affected by government more seriously than in the past.

The third reason why government is eager to promote public participation is that it promises a way of making poorly performing municipalities more responsive to communities. Indeed, the implementation of the ward committee system must be situated against the backdrop of a substantial community protest against deficiencies in local government. In late 2005, the Minister of Safety and Security, Charles Nqakula, reported to parliament that there had been 5085 protests country-wide in the previous year against issues like bad service delivery (Daily News, 14 October 2005). After initially laying the blame for the protests at the door of some 'third force', government appears to have recognised the genuine shortcomings of delivery and governance in many municipalities and, as a result, initiated the 'Project Consolidate' campaign (DPLG, 2004b: 4). In the lead-up to the local government elections of March 2006, ward committees enjoyed much affirmation as a result of this concern to improve the responsiveness and accountability of local government (see Mbeki, 2005). The ANC's (2006) election manifesto stated that:

Already we have put in place democratic institutions like Ward Committees and instituted participatory planning processes so that you can have a say in local social and economic development. Integrated Development Plans (IDPs) must rest on widespread consultation with the community. We are determined to strengthen popular forums to build an inclusive and truly developmental system of local government.

But how well are ward committees functioning, and are they making local government more accountable to residents? To answer this question we explored the operation of ward committees in the Msunduzi municipality.

\section{Local Democracy in Practice: The Msunduzi Case}

This section examines the establishment, composition, role and operation of ward committees in Msunduzi, with particular reference to whether they deepen democratic deliberation in local governance. Between August 2005 and March 2006, supported by a grant from the Centre for Civil Society, a series of in-depth and follow-up interviews and two focus group sessions were conducted with major role-players in Msunduzi, including 21 of the 37 ward councillors, key municipal officials, political party, organisational and civic leaders, and select ward committee members. These were supplemented with municipal and ward committee minutes, where available.

It was found that, leaving aside the fact that they lack decision-making powers, ward committees can indeed deepen local deliberation (and, therefore, democracy) if they (1) have competent ward councillors, (2) are not undermined by party political agendas and (3) are materially and institutionally supported by the council. In Msunduzi's case it was found that 
the required political will and resources were in short supply. Hence, the Speaker estimated that 'out of 37 ward committees 30 per cent are ok, 40 per cent are not functional and 30 per cent are working well', ${ }^{1}$ and the official in charge of ward committees described eight (22 per cent) of the ward committees as very functional, 17 (46 per cent) as somewhat functional, and 12 ( 32 per cent) as non-functional. ${ }^{2}$ This raises the possibility that instead of deepening democracy, ward committees could conceivably either succumb entirely to partisan party-political agendas, or - which may be the same thing - be used to deflect and defuse popular discontent. As it turns out, on the available evidence, both alternatives proved to be implausible. Disappointing their promoters and confounding their critics in equal measure, Msunduzi ward committees are just ineffectual.

Normally it is not possible to generalise from one case, but in this instance it can be assumed that the causes of the unremarkable performance of Msunduzi ward committees prevail elsewhere in the country. In the first place, Msunduzi is as typical a case as any municipality could be in South Africa, for a number of reasons. Demographically, its racial, age and gender profile is largely similar to most other municipalities, as is its average ward population (other than in the metropolitan municipalities), and its geographical scale is close to the median. Msunduzi's socio-economic profile is closer to the norm than most other municipalities as regards levels of unemployment, education and service provision, and it faces typical social issues (such as poverty, HIV/AIDS and crime). In addition, as in the vast majority of municipalities, the dominant party is the ANC, though there is a significant opposition party presence; and Pietermaritzburg is the capital city of the province of KwaZulu-Natal, although it is unclear how this affects ward-level politics. There are ethnic and language differences between Msunduzi and other municipalities (i.e. it is largely Zulu rather than Xhosa or Sotho) but these make little political difference in South African party politics. In the second place, and even more pertinently, in Msunduzi as elsewhere, the ward committee system is vulnerable to three relations of dependency on other local agents, one of which inheres in the design of the system, and two of which recur over much of the rest of the country. Consequently, there is good reason to believe that, in most wards in most municipalities, ward committees will operate pretty much as they do in Msunduzi inadequately. In making this case, we outline each of the three dependency relations ward committees are likely to find themselves in, beginning with the role of ward councillors.

\section{Dependence on the Ward Councillor}

The Msunduzi case makes it clear that even in a scenario where ward committees are properly established, clearly institutionalised into council processes, given the material resources and training to function properly, and free from party political interference, they still require a competent ward councillor to work. This is because ward committees are designed around the person of the ward councillor who convenes and chairs meetings, sets the agenda and, perhaps most importantly, acts as the sole conduit of information between the ward committee and the council. Should the ward councillor be incompetent, disorganised or just disinclined to use the ward committee system, there is little that ward committee members can do. Further, there is no incentive for ward councillors to make ward committees work, other than to impress party superiors should they regard ward committees as important structures. Indeed, the evidence suggests that ward committee members are often regarded by ward councillors either as 'useless' and thus a burden, or as 
competitors for their positions In short, effective ward committees are dependent upon an effective ward councillor, who has no inherent interest in the structure.

In the Msunduzi case, this dependency relation was evident in (1) the establishment and ongoing constitution of ward committees, (2) the representivity of some ward committees, as well as (3) the frequency and content of ward committee meetings. In September 2001 the Msunduzi municipality outsourced both the establishment of ward committees and the training of ward committee members to Lavender Development Specialists, a company comprised mostly of ANC-aligned lawyers and former councillors (Witness, 13 September 2001). 3 Lavender was given until Christmas 2001 to establish all 37 ward committees. However, by this deadline only 16 ward committees had been established, six of these in the Edendale area (Witness, 16 November 2001). Lavender was granted an extension to March 2002 (Witness, 28 December 2001) but, by mid-April 2002, nine wards (all or mostly in the Vulindlela area) were still without committees (Echo, 11 April 2002), and it was only by 2003 that some form of ward committee existed in all wards.

In addition to the delay in establishing ward committees, the process of constituting ward committees varied tremendously in practice, despite Lavender beginning with a standard approach. Some ward committees were elected at the first and only meeting, some from several meetings in different locations. Further, the election process itself varied from a show of hands, to ballot, to acclamation. Additional research revealed that, for various reasons, many ward committees became defunct and ceased to function. As many as eight of the original ward committees were later re-established or reformulated;4 and four of these eight ward committees were established directly and unilaterally by their respective ward councillor. 5

In this context of disorganisation around the constitution of ward committees, ward councillors played a central role both in determining the establishment process and the composition of ward committees. Naturally, ward councillors figure prominently (alongside the municipality or its representative, in this instance Lavender) in the legislation providing for the election of a ward committee and the calling of an initial ward meeting for that purpose (Notice 965 of 2005, Section 9). However, one interviewee, Mr Fred Wagner, claimed that the ward committee members in one particular ward (Ward 34) were neither nominated nor elected but simply co-opted onto the committee, 'just people [ward councillor] Adams could work with'.6 As leader of the Eastwood Community Forum, an organisation which has a history of conflict with the local ward councillor, Wagner's views may not be completely impartial; however, other ward councillors personally confirmed co-opting members as and when they saw the need arise. Notably, a handbook issued by the DPLG (2005: 29) cautions against the 'handpicking' of committee members. Perhaps the clearest example of this was in Ward 27 in the city centre. Here the ward councillor and almost all the committee are white business owners previously associated through a City Improvement District committee, many of whom were invited by the ward councillor to sit on the ward committee. 7 Hence, this ward committee more closely resembles a (white) local chamber of commerce rather than the resident population, which is almost fifty per cent black and middle- to low- income. 
Over and above the establishment and composition (and thereby representivity) of ward committees, the most profound way that ward councillors influenced ward committees was in terms of their operation. Ward councillors determined how often ward committees met, set the agendas for ward committees, and were the sole instrument through which information flowed between ward committees and council. Further, an examination of the frequency and number of meetings of ward committees suggests that many ward councillors were not doing their job properly - a view also expressed by the official in charge of the Msunduzi ward committee system. ${ }^{8}$ Our investigation revealed that less than fifty per cent of ward committees met regularly, despite two-year-old recommendations, now legislated, that they do so 'at least quarterly'. Even amongst those meeting regularly, the frequency varied widely, including weekly (Wards 10 and 34), monthly (Wards 28,29,30 and 32), bi-monthly (Wards 3 and 25) and annually (Ward 8). Most met irregularly (Wards 12,13,27 and 35) or only when an issue rendered a meeting necessary (Wards 5, 9, 11, 26, 33 and 37).

According to our survey, the following major issues were discussed at ward committee meetings (in order of frequency): sanitation and health; water; housing; transport; 'development' in a broad sense; crime; education; 'service delivery'; and 'rates and rents'. In more detail the list of issues is:

- $\quad$ sanitation and health (Wards 3, 8, 10, 19, 27, 28, 33, 34 and 35);

- water and drainage (Wards 1, 3, 8, 10, 19, 30, 34 and 35);

- housing (Wards 9, 10, 13, 26, 34, 35 and 37);

- transport and roads (Wards 1, 8, 10, 26, 30 and 37);

- 'development' (Wards 1, 9, 10, 11, 12 and 13);

- crime (Wards 25, 27, 28, 29 and 33);

- education, particularly school fees (Wards 28, 29, 30, 34 and 37);

- ' 'service delivery' (Wards 13, 19, 28 and 29);

- ' 'rates and rents' (Wards 19, 30, 33 and 35);

- unemployment (Wards 3, 28 and 29);

- illegal dumping and garden refuse (Wards 19, 25 and 30);

- grass cutting (Ward 33);

- HIV/AIDS (Wards 3 and 29);

- burials (Ward 9);

- welfare (Ward 10);

- pensions (Ward 3);

- youth recreational facilities (Ward 3);

- electricity (Ward 19);

- City Improvement District (Ward 27);

- tourism (Ward 27).

While some issues like sanitation, water, housing and rates appear to cross racial and socio-economic differences, they often mean quite different things in different wards. In addition, and bearing out a recent AC Nielsen survey of attitudes to local government (The Star, 22 May 2006), the concerns of the wealthier wards tend to be fixated on issues like crime, lighting and traffic calming, whereas the poorer wards are much more concerned with broader issues of development, housing, sanitation and service delivery. 
That this relation of dependency of ward committees vis-a-vis ward councillors is a central and potentially serious flaw in the ward committee system is further suggested by the difficulty of interviewing some 15 of the 37 ward councillors in Msunduzi. A significant number, around five, were not contactable, whilst others offered a variety of weak excuses that suggested a degree of disinterest or disillusionment with municipal politics. Further, this same problem is likely to be found across the country where similar conditions of inequality in material and cultural resources also apply. While it might be the case that the poor performance of many ward councillors in Msunduzi is exacerbated by party politics, or especially by limited council support for the ward committee system, it is logical to assume that even in the best-run municipalities there will be a few inept ward councillors and, therefore, a few non-functional ward committees.

\section{Dependence on the Party}

The Msunduzi case also revealed the significant influence that political parties have over ward committees. This takes three forms: (1) inter-party competition, (2) intra-party competition and (3) policy competition. Inter- party competition refers mainly to relations between the Inkatha Freedom Party (IFP) and the ANC, and the fact that all the IFP ward committees, many ANC ward committees and some Democratic Alliance (DA) ward committees appear to be subject to their respective party's control in terms of both composition and agenda-setting. At least 10 of the 37 wards fit into this category. According to the official in the Speaker's Office, 9 the 'politicisation' of ward committees is especially a problem in historically- black areas. The perception of the party politicisation of all IFP, many ANC and some DA ward committees seems to be shared by a range of respondents: from the DA ${ }^{10}$ and the African Christian Democratic Party (ACDP) ${ }^{11}$ to some Residents' or Ratepayers' Associations ${ }^{12}$ and the Speaker, Colin Gardner. ${ }^{13}$

Perhaps as pressing an issue, however, is intra-party factionalism within the ANC and, to a lesser extent, in other political parties. Mngadi described four of the 23 ANC ward committees (Wards 15, 16, 21 and 22) as highly politicised, explaining that some of the councillors saw themselves as 'the mayor's friends', a reference to the Thabo Mbeki/Jacob Zuma factionalism in the ANC. 14 Undercurrents of this kind of factionalism were detectable in respondents' views of the decision to outsource the establishment and training of ward committees to Lavender, against an earlier proposal by the City Planner's department that its Urbanisation Unit carry out this task. Recent raids by the Scorpions on Msunduzi officials have also been portrayed as part of an ongoing purge by the current 'Zuma' mayor against all associated with the tenure of the previous 'Mbeki' mayor (Witness, 30 August 2006).

There was also significant evidence of party-based differences about the very role of ward committees, with opposition parties, especially the DA, disinclined to conform to policy initiatives around the ward committee system advanced by ANC-aligned officials. This point was explicitly made by the official in charge of ward committees, ${ }^{15}$ who complained that the eight DA ward councillors largely ignored the municipality's initiatives around ward committees and insisted on 'doing things their way'. DA councillor Mr Bill Lambert denied that the DA's failure to attend Lavender's training programme was a party-based decision, explaining that his ward committee members were already experienced in these matters. ${ }^{16} \mathrm{~A}$ similar point was made by Mark Steel, DA proportional representation (P.R.) councillor. ${ }^{17}$ 
Whatever the true reason, the behaviour of DA ward committees tended to confirm Mngadi's claim about them doing things 'their way'.

The implications of partisan ward committees extend beyond just undermining their independent role, but also directly impact on the health of civil society, undermining its ability to engage the local council. This is because the establishment of ward committees has affected other organisations and structures already in existence in Msunduzi. In formerly advantaged white and Indian areas, Ratepayers' Associations had tended to carry out some of the functions now allocated to ward committees. One ward committee (Ward 25) was effectively taken over by the Ratepayers' Association; another (Ward 27) was either replaced, or was supplanted, by the existing Ratepayers' Association; while others (Wards 34 and 37) are said to be less effective, or to duplicate, previously existing community structures. Thus, to the extent that ward committees supplant other civil society formations in more advantaged areas, and these same ward committees remain colonised by party agendas, we see the effective extension of party authority over local areas. For champions of an independent civil society, it is fortunate - in an ironic sense - that many ward committees are simply not functioning, and thus cannot play this role. Nevertheless, the special status that ward committees enjoy as official structures of public participation, and the clear evidence of party dominance of ward committees, are not good news for state-society relations.

Lastly, there is reason to assume that the politicisation of ward committees and the potential demobilisation of civil society are problems that exist elsewhere in South Africa. Indeed, this can be seen as one more instance of the alleged 'dominant party syndrome' (see, among others, Butler, 2000; Brooks, 2004) associated with overwhelming and enduring ANC popularity, which is even more pronounced in many municipalities elsewhere in the country. The DPLG's Ward Committee Resource book states that 'there have been situations where party political influence has played a significant role in ward committee nomination processes', admitting that 'many ward committees are seen to be party-aligned' (DPLG, 2005: 31).

\section{Dependence on the Council}

Last, but not least, the Msunduzi case reveals the relations of dependence associated with the indispensability of municipal council support for (1) the proper establishment of ward committees and the managing of vacancies (both crucial for accurate 'community representation'), (2) role definition through institutional incorporation into council processes like the budget and IDP and (3) infrastructural, administrative and training needs. Such are the inequalities in material wealth and education in Msunduzi that the vast majority of residents remain marginal to the complex system of local governance. This places extra burdens on the municipality to empower residents to effectively engage in council processes.

We have already described the undue influence of ward councillors on the initial establishment of the Msunduzi ward committee system and on the management of vacancies. The lack of municipal oversight in these instances is all the more remarkable in the light of the Municipal Structures Act: 'If a vacancy occurs among the section 73(2)(b) members of a ward committee the vacancy must be filled in accordance with a procedure 
determined by the metro or local Council' (Section 76). In the event, it transpires that the Msunduzi municipality has yet to adopt clear policy on this, although the official in charge of public participation, Ms Sasa Mngadi, has been pushing for policy around these issues. It seems that, after the recent training workshops, the desire for greater guidance from the municipality on the composition and role of ward committees is widely felt. ${ }^{18}$

That the Msunduzi municipality has good reason to manage the formation and composition of ward committees more closely is reflected in shortcomings in the representation of women, traditional authorities and young people on ward committees. In respect of women, the Municipal Structures Act stipulates that ward committees must include 'equitable representation of women and of a diversity of interests in the ward'. Notice 965 of 2005 insists not only on 'equitable representation' but also on 'an even spread of men and women', and lists 'women' among some 20 specified interest groups (Section 7). In this light, women ward committee members are a grossly under-represented minority: the survey of 21 ward committees confirmed only 42 female members out of a possible total of 210. Even allowing for a generous margin of error, women do not comprise much more than 25 per cent of the total number of committee members.

A second anomaly concerns inconsistencies within national legislation regarding ward committees on the one hand and traditional authorities on the other. In certain parts of the Msunduzi region, the existence of the latter, coupled with uncertainty about their powers and functions, contributed to delays in the establishment and training of ward committees. Many of the functions of traditional councils duplicate the functions of ward committees, especially those relating to identifying community needs and assisting in the development of the IDP; in addition, sixty per cent of members of traditional councils are not elected, and women's representation is only required to be one-third at most (Legal Resources Centre, 2003; Traditional Leadership and Governance Framework, 2003). The Vulindlela area, containing a formal traditional authority which is also a stronghold of the IFP, was the last area in which ward committees were established, and a local ward councillor directly attributed the delay to the 'political intolerance of IFP izinduna' (Echo, 13 September 2001). The ANC and IFP eventually resolved their differences by agreeing that five committee members would be appointed by the Vulindlela Traditional Authority and five would be elected from the community (Echo, 11 April 2002).

A third anomaly concerns the under-representation of youth. Despite also being a designated interest group - in fact the first group listed in the 2005 Ministerial Notice young people made up just 26.8 per cent of the members of the ward committees interviewed, whereas the proportion of youth in these wards averages 41 per cent, according to 2001 census data. Among the many reasons given for youth under-representation was their supposed lack of maturity and training, but also, not least, the attitude of older people. In this regard, a comment by the councillor for Ward 3 is instructive:

Young people are not mature enough to involve them in government structures.... We need mature people and we should groom young people to play such roles. They should not be part of the process while still raw. We are talking about the lives of the people here. There should be training for them. ... Sometimes young people take this as a plaything and sometimes there is still that carelessness. ${ }^{19}$ 
If ward committees require council support to be properly constituted in a representative way, the evidence of Msunduzi also suggests they require clear institutionalisation into council processes to give meaning to their role. Though legislation makes room for ward committees to be included in public consultation processes around the IDP, the annual budget and bylaws, to date the Msunduzi municipality has not done this. Indeed, it has not added anything to the role of ward committees as advisory bodies to ward councillors, preferring, in the words of the Speaker, 'to see what local communities make of ward committees first'. ${ }^{20}$ In this context, even functional ward committees have tended to become 'toothless' bodies or 'talkshops', whose role is just to 'assist the ward councillor'. ${ }^{21}$

Further, the municipality has been found wanting in respect of both training and materially supporting ward committees. Having called for proposals for a 'capacity-building programme for ward committees, policy and process development' at the end of 2002, the municipality's Executive Committee resolved to appoint KPMG and Lavender 'in a joint venture on a 20/80 basis with KPMG providing the management and administration function and Lavender providing the training enterprise'. Fourteen weekly training sessions for three wards each week were envisaged, starting with the Vulindlela wards and followed by the Edendale ones, these wards being 'where training is most required' (Msunduzi Municipality, 2003). Despite these resolutions and plans, nothing materialised; eighteen months later, at the end of 2004, the City Manager was still pleading with Exco to 'sign the agreement that pertains to the above matter', namely 'Ward committee training by Lavender and KPMG' (Msunduzi Municipality, 2004), so that training could begin in January 2005.

This event notwithstanding, eight ward councillors confirmed that the training was late, delayed and/or inadequate. ${ }^{22}$ In duration, the training fell far short of what was originally envisaged, consisting of one week's training 23 or seven full-day workshops, ${ }^{24}$ without any suggestion that members might need to be trained on a regular basis. Roughly two-thirds of all ward committee members attended training in April 2005,25 but many of the remainder had still not been trained three months later (Mboto, 2005). Lavender's training modules Introduction to Local Government, Project Management, Municipal Finance and Budgeting, Local Economic Development and Integrated Development Plan - seemed better suited to training ward councillors, or people who can assist or even become ward councillors themselves, rather than fostering community development or participatory government practitioners (for whom modules on ethics or democracy might have been more relevant). In fact, the Ministerial Notices 2649 of 2003 and 965 of 2005, and the Resource Book on ward committees (DPLG, 2005: 6869), explicitly call for a much broader range of training areas, including 'community upliftment', 'conflict management', 'democracy and community participation', 'principles of good governance', 'leadership' and 'stress management'.

Lastly, the dependence of the ward committee system on the council was confirmed in the numerous references by ward councillors, committee members and officials to a shortage of finance and other resources. These include a lack of venues for meetings, ward committees having no budgets of their own, and committee members not being paid for their work nor compensated for costs incurred. This lack of support contributed to training, transport and administrative difficulties, but most of all offered few incentives to ward committee 
members and for the smooth functioning of committees. These problems are not isolated to the Msunduzi municipality: exactly the same concerns were expressed to former President Mbeki on a visit to the Northwest Province in May 2005, and across the country, a lack, or unproductive use, of both human and fiscal resources and capacity, coupled with confusion about roles and division of powers and insufficient cooperation, have been identified as the main challenges facing new-look local government (Witness, 3 November 2003; Carrim, 2003). Given the weakness of many of South Africa's 284 municipalities (half of which have been included in government's 'Operation Consolidate' programme intended to redress ineffectual local governance), beset with popular protests on the one hand and party machinations on the other, one wonders if government still envisages taking 'another 10 to 15 years to effectively implement the new model of local government that has begun to come into effect with the December 2000 elections' (Carrim, in Witness, 3 November 2003).

\section{Conclusion and Recommendations}

One of the most noteworthy findings of the Msunduzi case study was that all respondents thought that ward committees were a positive innovation. Some councillors observed that their views carried more weight with the council when supported by their ward committee. In theory, properly constituted, independent and well-functioning ward committees can improve the information exchange and deliberative aspects of key council processes and, in that sense at least, deepen local democracy in South Africa. Moreover, even dependence is always two-sided and, over time, councillors, parties and municipalities may in various ways become more reliant on ward committees. 'Any field of rule can be represented as a network of interdependent people and groups acting with or against each other in certain directions' (Elias, 1983: 119) and, thus, no matter how lopsided the sub-local government 'field of rule' may currently appear to be, we cannot discount the possibility that the continued existence and gradually improved operation of ward committees will both increasingly restrain councillors, municipalities and parties, even while enhancing opportunities to influence participation, deliberation and even decision making on the part of committee members.

The problem certainly remains the everyday practice. In Msunduzi, between a third and a half of all ward committees are not functioning properly, if at all. They are dominated by councillors and political parties rather than by the community as a whole, and neglected by the municipality. These are good reasons to be sceptical about the democratic dividend that the ward committee system is likely to yield anywhere in South Africa. Nevertheless, it is a popular myth that democracy requires the freest possible competition between interest groups, or at least that it is incompatible with the overwhelming dominance of a single political party. On the contrary, democracy 'presupposes highly organized monopolies, and it can only come into being or survive under certain conditions, in a very specific social structure at a very advanced stage of monopoly formation' (Elias, 1982: 115). In this regard, perhaps it is understandable that the dependence of ward committees on the sanction of party - not to mention councillor - can be described as 'unsurprising' (DPLG, 2005: 31). Notably, it is possible that this need not be a bad thing for democratic consolidation (see Piper \& Deacon, 2008 for a discussion of this claim). 
Furthermore, there is a fourth kind of dependency that hamstrings the effective working of ward committees, a kind of 'popular acquiescence' that often lurked in the background of conversations with respondents. Notably, throughout all the legislation concerned with ward committees, there tends to be an assumption of participation, that is, of the likelihood of there usually being more than enough, rather than insufficient, candidates to fill the maximum places available on each ward committee; and that the community will see the ward committee as legitimate. Yet, it seems a little strange to assume participation in structures supposed to enhance participation. Indeed, many respondents referred to the ignorance of residents with regard to the workings of local government, with one going so far as to say that '[people] often do not know what their needs are'. ${ }^{26}$ Others, referring to the relatively banal nature of local government in more developed wards, lamented the apathy of many residents. In a context where, for whatever the reasons, ignorance and apathy are widespread, an effective ward committee system is made much more difficult. However, to lay the blame for a poorly functioning ward committee system solely on popular acquiescence would be unfair, especially in the light of some significant counter-evidence in terms of relatively high participation levels in local and national government elections.

All these dependency relations notwithstanding, there is some reason to believe that municipalities will come to support the ward committee system, and 'participatory governance', a little better in the future. For example, several provincial governments, including KwaZulu-Natal, have developed - or are in the process of developing - practical guides on how to run ward committees and public participation processes. Furthermore, recent initiatives in respect of intergovernmental relations have put in place new structures and procedures that will allow district and provincial spheres to help local municipalities meet these challenges.

Perhaps it is too early in the policy implementation phase to definitively discount the deliberative benefits of ward committees for local government.

However, if ward committees are to realise their potential then a lot more needs to be done, or done better. Immediate efforts should be made to dilute the overwhelming influence of the ward councillor by instituting regular committee meetings, specified in advance; by introducing specified portfolios related to key performance areas and recognised interest groups; by ensuring that issues emerging from or being relayed back to ward committees are standing items on council agendas; and by specifying a legal minimum number of members, so as to facilitate quorate decision making. Notice 965 of 2005 allows for ward committees to 'express dissatisfaction in writing to the municipal council on the non-performance of a ward councillor' (Section 5(3)(e)), but councillors would be rendered far more accountable and responsive to their wards if such expressions of dissatisfaction could lead to disciplinary procedures and material sanctions.

In respect of party dominance, pluralism can be expected to grow slowly but steadily in 
KwaZulu-Natal as ANC/IFP conflict declines. However, local competition for political jobs will remain as long as poverty grips the majority. In this context, ward committees are more likely to represent local factions, networks or individuals than the community at large. But, so long as political contestation remains within bounds, the community may well benefit from the galvanising and edifying effects of differences of opinion. Some things are important enough to be partisan about, as both the recent protests against poor service delivery and the national government response seems to suggest. This is because 'democracy is not something a society "gets"; democracy must be fought for each and every day in concrete instances, even long after democracy is first constituted in a society' (Flyvbjerg, 1998: 5).

Finally, municipalities should move rapidly to overcome representational inequities, particularly with regard to women, youth and previously disadvantaged groups; and promulgate clearly defined procedures for electing, co-opting and replacing committee members. Municipalities also need to improve channels of communication; honour their legal obligations to provide training (for councillors as much as committee members) and administrative and clerical support; and directly involve ward committees in processes of public consultation around the budget, the IDP, by-laws and service agreements.

\section{Notes}

1 Interview with Colin Gardner, Speaker, Msunduzi Local Council, 11 August 2005.

2 Interview with Sasa Mngadi, Official in the Speaker's Office, in charge of public participation, Msunduzi Local Council, 7 March 2006.

3 See note 1.

4 Wards 13, 19, 25, 27, 28, 29, 30 and 34 .

5 Wards 13, 27, 28 and 29.

6 Interview with Fred Wagner, Chairperson: Eastwood Community Forum, 30 October 2005.

7 Interview with K. Blomeyer, Ward 27 ward councillor, 25 August 2005.

${ }_{8}$ See note 2.

9 Ibid.

10 Interview with M.H. Steel, DA P.R. councillor, Msunduzi Local Council, 20 February 2006.

11 Interview with Mrs Pillay, ACDP P.R. councillor, Msunduzi Local Council, 20 February 2006.

12 Interview with L.E.M. Nkosi, Ward 12 ward councillor and Chairperson: Edendale Land Owners and Ratepayers' Association, 6 September and 17 October 2005. Interview with Paul Thompson, Acting Secretary: Scottsville Residents' Association, and ward committee member, Ward 36, 3 March 2006.

13 See note 1.

14 In Msunduzi, this takes the form of former mayor Zweli Hloni and his associates being aligned to Mbeki and Provincial Premier Ndebele, with new mayor Zanele Hlatswayo and associates being aligned to Zuma and Provincial MEC for Economic Affairs, Zweli Mkhize.

15 Interview with Sasa Mngadi (note 1), 11 August 2005.

16 Interview with W. Lambert, Ward 25 ward councillor, 18 August 2005.

17 See note 10. 
18 See notes 1 and 2.

19 Interview by Nonhlanhla Chanza, UKZN Masters Candidate, with the Ward Councillor for Ward 3, 5 December 2005.

20 See note 1.

21 Interviews with T. Zondi, Ward 19 ward councillor, 19 August 2005, W. Lambert (note 16) and L.E.M. Nkosi (note 12).

22 From Wards 5, 10, 12, 13, 26, 29, 32 and 34.

23 See note 1.

24 Interview with W.V. Adams, Ward 34 ward councillor, 25 August 2005.

25 See note 2.

26 Interview with N. Ahmed, Ward 19 ward councillor, 19 September 2005. 


\section{References}

ANC (1986) From ungovernability to people's power - 1986. Available at: http://www.anc.org. za/ancdocs/history/keydocs.html (accessed 11 November 2007).

ANC (2006) 2006 Local Government Manifesto: A Plan to Make Local Government Work Better for You. Available at: http://www.anc.org.za/elections/2006/index.php?id=manifesto.html $\quad$ (accessed 11 November 2007).

Brooks, H. (2004) The dominant party system: challenges for South Africa's second decade of democracy, Journal of African Elections, 3(2), pp.121-153.

Bryan, F.M. (2004) Real Democracy: The New England Town Meeting and How It Works (Chicago: University of Chicago Press).

Butler, A. (2000) Is South Africa heading towards authoritarian rule? Instability myths and expectations traps in a new democracy, Politikon, 27(2), pp.189-206.

Carrim, Y. (2003) Bridging the gap between the ideas and practice: challenges of the new local government system. Available at: http://www.anc.org.za/ancdocs/pubs/umrabulo/ umrabulo10c.html (accessed 11 November 2007).

DPLG (2004a) Ward Committees (Pretoria: Department of Provincial and Local Government).

DPLG (2004b) Project 'Consolidate!' A Hands-On Local Government Engagement Programme for 2004-06 (Pretoria: Department of Provincial and Local Government). Available at: http://www.projectconsolidate.gov.za/docs/Base Document.pdf (accessed 11 November 2007).

DPLG (2005) Making Ward Committees Function: Resource Book: Best Practices and Lessons Learnt (Pretoria: Department of Provincial and Local Government/German Agency for Technical Co-operation).

Elias, N. (1982) The Civilising Process, vol. 2: State Formation and Civilization (Oxford: Blackwell).

Elias, N. (1983) The Court Society (Oxford: Blackwell).

Flyvbjerg, B. (1998) Rationality and Power: Democracy in Practice (Chicago: University of Chicago Press).

Legal Resources Centre (2003) Submission on the Draft Guidelines for the Establishment and Operation of Municipal Ward Committees, 2003. Available at: http://66.249.93.104/custom? q=cache:eBtQGdUlHRYJ:www.lrc.org.za/Docs/File Download.asp\%.3FThisPath\%3D../ File_Uploads/Docs/\%26ThisFile\%3D12_Guidelines_wardcomitees_20Nov.doc + ward + committee\&hl=en\&ct $=$ clnk\&cd $=1$ \&ie $=$ UTF-8 $($ accessed 11 November 2007).

Local Government Municipal Structures Act (1998) Act no. 117. Available at: www.info.gov.za/gazette/acts/1998/a117-98.pdf (accessed 11 November 2007).

Local Government Municipal Structures Act (2000) Act no. 32. Available at: www.info.gov.za/ gazette/acts/2000/a32-00.pdf (accessed 11 November 2007).

Mbeki, T. (2005) Media briefing by President Thabo Mbeki on Cabinet Lekgotla, 24 July 2005. Available at: http://www.info.gov.za/speeches/2005/05072509551001.htm (accessed 11 November 2007).

Mboto, S. (2005) Training for ward committees, 21 July 2005. Available at: http://www. sacities.net/2005/jul25_msunduzi.stm (accessed 11 November 2007).

Msengana-Ndlela, L. (2006) Speech by Ms Lindiwe Msengana-Ndlela, Director-General of the Department of Provincial and Local Government (DPLG) to the Conference of the 
Development Bank of Southern Africa, Vulindlela Academy (DVA), Midrand, Johannesburg, 13 March $2006 . \quad$ Available http://www.dplg.gov.za/speeches/13Mar2006DGv1.doc (accessed 11 November 2007). Msunduzi Municipality (2003) Report by Department of the City Planner to ExCo, 3 June.

Msunduzi Municipality (2004) Report by Acting Manager, Office of the City Manager to ExCo, 8 December.

Notice 2649 (2003) Draft guidelines for the establishment and operation of municipal ward committees, Government Gazette, 24 October.

Notice 965 (2005) Guidelines for the establishment and operation of municipal ward committees, Government Gazette, 24 June.

Piper, L. \& Deacon, R. (2008) Party politics, elite accountability and public participation: ward committee politics in the Msunduzi Municipality, Transformation, 66/67, pp.61-82.

Traditional Leadership and Governance Framework Act (2003) Act no. 41. Available at: http:// www.info.gov.za/gazette/acts/2003/a41-03.pdf (accessed 11 November 2007).

Vanderhaegen, Y. (2005) Local government, The Witness Newspaper, 4 March. 